\title{
Growth, Morphology, and Quality of Rooted Cuttings of Several Herbaceous Annual Bedding Plants Are Influenced by Photosynthetic Daily Light Integral During Root Development
}

\author{
Christopher J. Currey, Veronica A. Hutchinson, and \\ Roberto G. Lopez ${ }^{1,2}$ \\ Department of Horticulture and Landscape Architecture, Purdue University, \\ 625 Agriculture Mall Drive, West Lafayette, IN 47907-2010
}

Additional index words. DLI, quality index, sturdiness quotient, vegetative propagation

\begin{abstract}
Cuttings of herbaceous annual bedding plants must be rooted in late winter and early spring when ambient outdoor photosynthetic daily light integrals (DLIs) are at seasonally low levels. We evaluated the effect of DLI during root development on growth, morphology, and quality of nine popular vegetatively propagated annual bedding plant species. Cuttings of Angelonia angustifolia Benth. 'AngelMist White Cloud', Argyranthemum frutescens (L.) Sch. Bip. 'Madeira Cherry Red', Diascia barberae Hook. f. 'Wink Coral', Lantana camara L. 'Lucky Gold', Nemesia fruticans (Thunb.) Benth. 'Aromatica Royal', Osteospermum ecklonis (DC.) Norl. 'Voltage Yellow', Scaevola L. hybrid 'Blue Print', Sutera cordata Roth. 'Abunda Giant White', and Verbena Ruiz $\times$ hybrida 'Aztec Violet' were harvested and propagated in a glass-glazed greenhouse with $23{ }^{\circ} \mathrm{C}$ air and substrate temperature set points. After callusing $\left(\approx 5 \mathrm{~mol} \cdot \mathrm{m}^{-2} \cdot \mathrm{d}^{-1}\right.$ for 7 days $)$, cuttings of each species were placed under one of three different fixed-woven shade cloths providing $\approx 38 \%, 61 \%$, or $86 \%$ shade or no shade with $16 \mathrm{~h}$ of supplemental light for 14 days. There were no clear trends across species for stem length in response to DLI. Stem caliper of Argyranthemum, Diascia, and Nemesia increased by 35\%, 119\%, and 89\%, respectively, as DLI increased from 1.2 to $12.3 \mathrm{~mol} \cdot \mathrm{m}^{-2} \cdot \mathrm{d}^{-1}$. Depending on species, total, shoot, and root dry mass increased by $64 \%$ to $465 \%, 50 \%$ to $384 \%$, and $156 \%$ to $1137 \%$, respectively, as DLI increased from 1.2 to $12.3 \mathrm{~mol} \cdot \mathrm{m}^{-2} \cdot \mathrm{d}^{-1}$. The quality index, an objective, integrated, and quantitative measurement of rooted cutting quality, increased for all species by $176 \%$ to $858 \%$ as DLI increased from 1.2 to $12.3 \mathrm{~mol} \cdot \mathrm{m}^{-2} \cdot \mathrm{d}^{-1}$. Our results indicate that providing a DLI of $\approx 8$ to $12 \mathrm{~mol} \cdot \mathrm{m}^{-2} \cdot \mathrm{d}^{-1}$ after callusing increases both growth and quality of rooted cuttings.
\end{abstract}

Bedding plants are the highest revenue sector of the U.S. floriculture industry with a wholesale value over $\$ 1.91$ billion for the 15 top-producing states (U.S. Department of Agriculture, 2011). Young plants propagated

\footnotetext{
Received for publication 28 June 2011. Accepted for publication 5 Oct. 2011.

We gratefully acknowledge Diane Camberato, Rob Eddy, and Dan Hahn for greenhouse assistance, funding from growers providing support for Purdue University floriculture research, and support from the Purdue Agricultural Experiment Station. We thank Ball Horticultural Co. for plant material, Conrad Fafard, Inc. for substrate, Ludvig Svensson for shade cloth, J.R. Peters, Inc. for fertilizer, and the Indiana Flower Growers Association, Fred. C. Gloeckner Foundation, Inc., and U.S.D.A. NIFA Specialty Crop Research Initiative award no. 2010-51181-21369 for support.

The use of trade names in this publication does not imply endorsement by Purdue University of products named nor criticism of similar ones not mentioned.

${ }^{1}$ Assistant Professor and Extension Specialist.

${ }^{2}$ To whom reprint requests should be addressed; e-mailrglopez@purdue.edu.
}

from seed (plugs) or shoot-tip cuttings (liners) are commonly used in herbaceous ornamental annual bedding plant production and propagative material for this use is currently valued at over \$166 million (U.S. Department of Agriculture, 2011). Compared with young plants propagated from seed, rooted cuttings have increased genetic uniformity, no juvenile stage to pass before flowering, shorter production time, and the potential to be produced from sterile or seedless cultivars (Erwin, 1994).

The goals of propagators include producing high-quality rooted cuttings by maximizing root growth, total mass, root-to-shoot mass ratio, and stem caliper while minimizing production time and stem elongation (Lopez and Runkle, 2008; Pramuk and Runkle, 2005). To meet the spring and early summer market demand for flowering bedding plants, cuttings are typically rooted in mid- to late winter and early spring when ambient outdoor DLIs are at seasonally low levels (Korczynski et al., 2002). Further reductions in greenhouse DLIs often result from glazing material and interior structures (Hanan, 1998), as well as hanging baskets suspended above benches for additional bedding plant production (Faust, 2004). For instance, greenhouse DLIs across the northern United States in January may be as low as 2-6 $\mathrm{mol} \cdot \mathrm{m}^{-2} \cdot \mathrm{d}^{-1}$ as a result of reductions of outdoor DLIs by up to $60 \%$ (Korczynski et al., 2002; Lopez and Runkle, 2008).

Light impacts growth, morphology, and quality of seedlings (Graper and Healy, 1991; Oh et al., 2010; Pramuk and Runkle, 2005; Torres and Lopez, 2011) and rooted cuttings (Lopez and Runkle, 2008). Although recommendations for light during root development are given in instantaneous units $\left(\mu \mathrm{mol} \cdot \mathrm{m}^{-2} \cdot \mathrm{s}^{-1}\right.$; Dole et al., 2006), photosynthetic photon flux $(P P F)$ varies greatly over a day, month, and season (Lambers et al., 2008; Larcher, 2003), and a more accurate description of $P P F$ during crop production is the integrated photosynthetic DLI, expressed as $\mathrm{mol} \cdot \mathrm{m}^{-2} \cdot \mathrm{d}^{-1}$.

Lopez and Runkle (2008) quantified the effects of DLI during propagation on Impatiens hawkeri W. Bull (New Guinea impatiens) and Petunia $\times$ hybrida hort. Vilm.-Andr. (petunia). However, the effects of using supplemental lighting to increase DLI during cutting propagation of a broader range of specialty herbaceous annual bedding plants has not been reported. Therefore, our objectives were to quantify the impact of DLI during propagation on growth, morphology, and quality of several vegetatively propagated annual bedding plant species.

\section{Materials and Methods}

Plant material and culture. Stock plants of Angelonia angustifolia 'AngelMist White Cloud', Argyranthemum frutescens 'Madeira Cherry Red', Diascia barberae 'Wink Coral', Lantana camara 'Lucky Gold', Nemesia fruticans 'Aromatica Royal', Osteospermum ecklonis 'Voltage Yellow', Scaevola hybrid 'Blue Print', Sutera cordata 'Abunda Giant White', and Verbena $\times$ hybrida 'Aztec Violet' were planted in $15-\mathrm{cm}$ (1.7-L volume) round containers filled with substrate comprised of (v/v) $80 \%$ sphagnum peatmoss and $20 \%$ perlite (Fafard 1P; Conrad Fafard, Inc., Agawam, MA) on 9 May 2010. Plants were irrigated with acidified water supplemented with a combination of $900 \mathrm{mg} \cdot \mathrm{L}^{-1} 15 \mathrm{~N}-2.2 \mathrm{P}-12.5 \mathrm{~K}$ Cal-Mag (Peters Excel@; The Scotts Co., Marysville, $\mathrm{OH}$ ) and $300 \mathrm{mg} \cdot \mathrm{L}^{-1} 21 \mathrm{~N}-2.2 \mathrm{P}$ 16.6K (Peters Excel@; The Scotts Co.) watersoluble fertilizers to provide (in $\mathrm{mg} \cdot \mathrm{L}^{-1}$ ): 200 nitrogen, 26 phosphorus, 163 potassium, 50 calcium, 20 magnesium, 0.22 boron, 0.14 copper, 1.0 iron, 0.37 manganese, 0.23 molybdenum, and 0.52 zinc. Irrigation water was supplemented with $93 \%$ sulfuric acid (Brenntag, Reading, PA) at $0.08 \mathrm{~mL} \cdot \mathrm{L}^{-1}$ to reduce alkalinity to $100 \mathrm{mg} \cdot \mathrm{L}^{-1}$ and $\mathrm{pH}$ to a range of 5.7 to 6.0 . Stock plants were maintained in a vegetative state by regularly pinching shoots and applying foliar sprays of solutions containing $250 \mathrm{mg} \cdot \mathrm{L}^{-1}$ ethephon (Florel; Rhône-Poulenc Ag Company, Research Triangle Park, NC) every 2 weeks. Ethephon sprays were discontinued at least 3 weeks preceding cutting harvest.

The plants were grown in a glass-glazed greenhouse in West Lafayette, IN (lat. $40^{\circ} \mathrm{N}$ ) 
with an exhaust fan and evaporative-pad cooling and radiant hot-water heating controlled by an environmental computer (Maximizer Precision 10; Priva Computers Inc., Vineland Station, Ontario, Canada). The greenhouse day and night air temperature set points were $23 \pm 1{ }^{\circ} \mathrm{C}$. The photoperiod was a constant $16 \mathrm{~h}$ (0600 to $2200 \mathrm{HR})$ consisting of natural daylengths with day-extension lighting from high-pressure sodium lamps (HPS) that delivered a supplemental $P P F$ of $108.9 \pm$ $5.2 \mu \mathrm{mol} \cdot \mathrm{m}^{-2} \cdot \mathrm{s}^{-1}$ at plant height [as measured with a quantum sensor (LI-COR Biosciences, Lincoln, NE)] when outdoor irradiance was less than $250 \mu \mathrm{mol} \cdot \mathrm{m}^{-2} \cdot \mathrm{s}^{-1}$ from 0600 to $2200 \mathrm{HR}$. An automatic woven shade curtain (OLS 50; Ludvig Svensson Inc., Charlotte, NC) was retracted when the outdoor light intensity exceeded $\approx 1000 \mu \mathrm{mol} \cdot \mathrm{m}^{-2} \cdot \mathrm{s}^{-1}$ throughout the study to prevent leaf scorch. Greenhouse air temperature and DLI were measured with an enclosed thermocouple and quantum sensor, respectively (Watchdog 2450 Weather Station; Spectrum Technologies, Inc., Plainfield, IL). The mean greenhouse air temperature and DLI for stock plants was $23.2 \pm 1.2{ }^{\circ} \mathrm{C}$ and $11.6 \pm 2.0 \mathrm{~mol} \cdot \mathrm{m}^{-2} \cdot \mathrm{d}^{-1}$, respectively.

Cutting harvest. Forty uniform $2.5-\mathrm{cm}$ shoot-tip cuttings of every species were harvested from stock plants on 4 Sept. 2010, 16 Oct. 2010, and 11 Jan. 2011. Cuttings were placed in 105-cell propagation trays $(28-\mathrm{mL}$ individual cell volume; T.O. Plastics, Inc., Clearwater, MN) filled with a propagation substrate composed of (v/v) 50\% soilless substrate (Fafard 1P; Conrad Fafard, Inc.) and $50 \%$ coarse perlite (Strong-Lite Coarse Perlite; Sun Gro Horticulture, Bellevue, WA). Cuttings were sprayed to runoff with a solution containing $300 \mathrm{mg} \cdot \mathrm{L}^{-1}$ non-ionic surfactant (CapSil; Aquatrols, Paulsboro, NJ) so that water would not accumulate on the plant foliage.

Propagation environment and culture. All cuttings were placed in a glass-glazed greenhouse under a 16-h photoperiod with air and substrate temperature set points of $23 \pm 1{ }^{\circ} \mathrm{C}$ and a DLI maintained at $\approx 5 \mathrm{~mol} \cdot \mathrm{m}^{-2} \cdot \mathrm{d}^{-1}$ for callusing. Resistance-based sensors (External Temperature Sensor; Spectrum Technologies, Inc.) recorded air and substrate temperatures every $30 \mathrm{~s}$ and averages were logged every $15 \mathrm{~min}$ by a data logger (Watchdog 2800 Weather Station; Spectrum Technologies, Inc.). Two amplified quantum sensors (SQ-212; Apogee Instruments, Inc., Logan, UT) measured $P P F$ every $30 \mathrm{~s}$ under each lighting treatment, and the average of each sensor was logged every $15 \mathrm{~min}$ by a data logger (Watchdog 2800 Weather Station; Spectrum Technologies, Inc.). Environmental data during callusing are reported in Table 1 .

After $7 \mathrm{~d}$ of callusing, 10 cuttings of each species were placed under DLI treatments that were created using no shade or fixedwoven shadecloth providing $\approx 0 \%, 38 \%$, $61 \%$, or $86 \%$ shade (XLS F-14, -15 , or -16 , respectively; Ludvig Svensson, Inc., Charlotte, NC) under ambient daylight supplemented with a $P P F$ of $78.7 \pm 8.0,43.7 \pm 4.9,32.9 \pm$ 4.9 , or $13.1 \pm 2.1 \mu \mathrm{mol} \cdot \mathrm{m}^{-2} \cdot \mathrm{s}^{-1}$ at plant height [as measured with a quantum sensor
(LI-COR Biosciences)], respectively, delivered from HPS lamps from 0600 to $2000 \mathrm{HR}$. An automatic woven shade curtain was retracted as previously described.

Every $20 \mathrm{~min}, 4 \mathrm{~s}$ of mist was applied consisting of tap water supplemented with a water-soluble fertilizer (Jack's LX 16N0.94P-12.3K Plug Formula for High Alkalinity Water; J.R. Peters, Inc., Allentown, PA) providing (in $\mathrm{mg} \cdot \mathrm{L}^{-1}$ ) with each misting event: 50 nitrogen, 5 phosphorus, 39 potassium, 9 calcium, 4.7 magnesium, 0.05 boron, 0.025 copper, 0.25 iron, 0.125 manganese, 0.025 molybdenum, and 0.125 zinc. Six d after transfer of cuttings, misting frequency was reduced to every $30 \mathrm{~min}$ beginning and ending $2 \mathrm{~h}$ before and after the photoperiod, respectively; $8 \mathrm{~d}$ after cutting transfer, misting was reduced to begin and end $1 \mathrm{~h}$ before and after the photoperiod. Ten $\mathrm{d}$ after the placement of cuttings under DLI treatments, the use of mist was discontinued and cuttings were hand-irrigated daily with acidified water supplemented with water-soluble fertilizer as described in the "Plant Material and Culture" section. Environmental data under each treatment were measured as previously described and are reported in Table 2.

Data collected. Data were collected $14 \mathrm{~d}$ after cuttings were placed under DLI treatments. Cuttings were removed from propagation trays and substrate was gently rinsed off the roots. Stem caliper above the lowest leaf and stem length from the base of the cutting to the apical meristem were measured with a digital caliper (digiMax; Wiha, Schonach, Germany). Roots were excised from the cutting and roots and shoots were dried separately in an oven at $70{ }^{\circ} \mathrm{C}$ for $3 \mathrm{~d}$ and then weighed. Total dry mass (shoot dry mass + root dry

Table 1. Average daily greenhouse air and substrate temperatures and daily light integral (DLI) during callusing of nine vegetatively propagated annuals before being placed under DLI treatments.

\begin{tabular}{lccc}
\hline & \multicolumn{2}{c}{ Temperature $\left({ }^{\circ} \mathrm{C}\right)$} & \\
\cline { 2 - 3 } Propagation date & Air & Substrate & DLI $\left(\mathrm{mol}^{\circ} \cdot \mathrm{m}^{-2} \cdot \mathrm{d}^{-1}\right)$ \\
\hline 4 Sept. 2010 & $21.3 \pm 0.5$ & $22.7 \pm 0.5$ & $5.0 \pm 0.9$ \\
17 Oct. 2010 & $20.9 \pm 0.8$ & $22.6 \pm 0.9$ & $4.7 \pm 1.2$ \\
11 Jan. 2011 & $20.7 \pm 1.1$ & $22.4 \pm 1.5$ & $4.8 \pm 0.7$ \\
\hline
\end{tabular}

Table 2. Average daily greenhouse air and substrate temperatures and daily light integral (DLI) during root development of nine vegetatively propagated annuals under no shade $(0 \%)$ or $\approx 38 \%, 61 \%$, or $86 \%$ shade (XLS-14, -16, or -18; Ludvig Svensson, Inc., Charlotte, NC) under ambient daylight supplemented with $78.7 \pm 8.0,43.7 \pm 4.9,32.9 \pm 4.9$, or $13.1 \pm 2.1 \mu \mathrm{mol} \cdot \mathrm{m}^{-2} \cdot \mathrm{s}^{-1}$, respectively, delivered from high-pressure sodium lamps from 0600 to $2000 \mathrm{HR}$.

\begin{tabular}{|c|c|c|c|c|}
\hline \multirow[b]{2}{*}{ Propagation Date } & \multirow[b]{2}{*}{ Shade $(\%)$} & \multicolumn{2}{|c|}{ Temperature $\left({ }^{\circ} \mathrm{C}\right)$} & \multirow[b]{2}{*}{$\operatorname{DLI}\left(\mathrm{mol} \cdot \mathrm{m}^{-2} \cdot \mathrm{d}^{-1}\right)$} \\
\hline & & Air & Substrate & \\
\hline \multirow[t]{4}{*}{4 Sept. 2010} & 0 & $22.2 \pm 0.8$ & $22.6 \pm 0.5$ & $12.3 \pm 1.5$ \\
\hline & 38 & $21.9 \pm 0.8$ & $22.1 \pm 0.3$ & $7.2 \pm 1.2$ \\
\hline & 61 & $22.1 \pm 0.7$ & $22.2 \pm 0.7$ & $5.6 \pm 1.2$ \\
\hline & 86 & $21.9 \pm 0.8$ & $23.7 \pm 1.1$ & $2.0 \pm 0.4$ \\
\hline \multirow[t]{4}{*}{17 Oct. 2010} & 0 & $22.4 \pm 0.3$ & $23.1 \pm 0.4$ & $10.6 \pm 1.4$ \\
\hline & 38 & $22.3 \pm 0.6$ & $22.4 \pm 0.4$ & $6.4 \pm 0.8$ \\
\hline & 61 & $21.6 \pm 0.8$ & $22.0 \pm 0.3$ & $3.6 \pm 0.4$ \\
\hline & 86 & $21.9 \pm 0.5$ & $22.1 \pm 0.3$ & $1.4 \pm 0.2$ \\
\hline \multirow[t]{4}{*}{11 Jan. 2011} & 0 & $21.8 \pm 0.6$ & $22.4 \pm 0.6$ & $9.0 \pm 0.9$ \\
\hline & 38 & $21.9 \pm 0.7$ & $21.9 \pm 0.2$ & $4.9 \pm 0.8$ \\
\hline & 61 & $21.8 \pm 0.6$ & $22.0 \pm 0.3$ & $2.8 \pm 0.8$ \\
\hline & 86 & $22.4 \pm 0.7$ & $23.0 \pm 0.6$ & $1.2 \pm 0.4$ \\
\hline
\end{tabular}




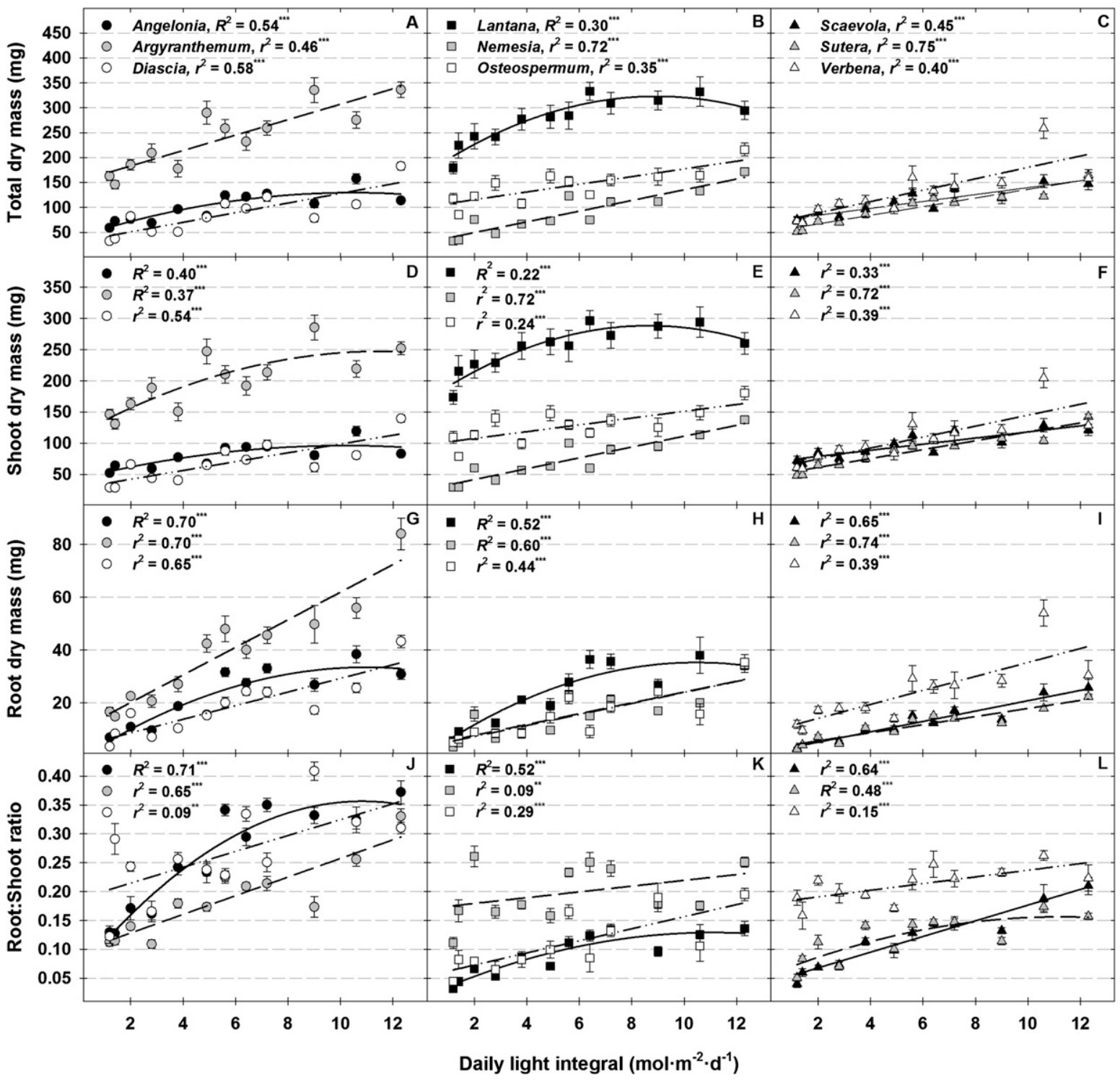

Fig. 1. (A-L) Relationships between mean daily light integral (DLI) and total dry mass, shoot dry mass, root dry mass, and root:shoot dry mass ratio of Angelonia, Argyranthemum, Diascia, Lantana, Nemesia, Osteospermum, Scaevola, Sutera, and Verbena measured after 14 d under different DLIs during propagation. Each symbol represents the mean of 10 plants, and error bars represent SEs of the mean. Regression lines are presented for significant correlations only with corresponding $r^{2}$ and $R^{2}$ presented. Ns, $*, * *, * *$ indicates nonsignificant or significant at $P \leq 0.05,0.01$, or 0.001 , respectively. Species are grouped alphabetically within rows from $\mathrm{L}$ to $\mathrm{R}$ for each dependent variable.

(106 mg; Argyranthemum), whereas shoot dry mass of Diascia, Nemesia, Sutera, and Verbena increased by $110 \%$ (67 $\mathrm{mg}$; Verbena) to $384 \%$ (111 mg; Diascia) (Fig. 1D-F). Increasing DLI during propagation increased the root dry mass for all nine species (Fig. 1G-I). For example, increasing the DLI from 1.2 to $12.3 \mathrm{~mol} \cdot \mathrm{m}^{-2} \cdot \mathrm{d}^{-1}$ resulted in a $19-\mathrm{mg}$ increase $(156 \%)$ in root dry mass of Verbena (Fig. 2I), whereas root dry mass of Diascia increased by $40 \mathrm{mg}$ (1137\%) (Fig. 1G). Additionally, the root:shoot dry mass ratio increased for all species as DLI during propagation increased (Fig. 1J-L). Although the root:shoot ratio of Verbena increased by 0.03 (18\%) as DLI during propagation increased, the root:shoot ratio of Osteospermum and Scaevola increased by $0.15(329 \%)$ and $0.17(419 \%)$, respectively (Fig. 1H-I).

Morphology. Stem length of species was affected differently by DLI during propagation
(Fig. 2A-C). For example, stem length of Lantana and Nemesia increased by $0.7(20 \%)$ and $1.9 \mathrm{~cm}(20 \%)$, respectively, as DLI during propagation increased from 1.2 to 12.3 $\mathrm{mol} \cdot \mathrm{m}^{-2} \cdot \mathrm{d}^{-1}$ (Fig. 2B), whereas stem length of Diascia increased by $5.3 \mathrm{~cm}(76 \%)$ (Fig. 2A). Stem length of Argyranthemum, Osteospermum, and Scaevola was unaffected by DLI during propagation (Fig. 2A-C). Whereas stem caliper of Lantana, Scaevola, and Sutera was unaffected by DLI, stem caliper of Angelonia, Argyranthemum, Diascia, Nemesia, Osteospermum, and Verbena increased with DLI during propagation (Fig. 2D-F). As DLI increased from 1.2 to $12.3 \mathrm{~mol} \cdot \mathrm{m}^{-2} \cdot \mathrm{d}^{-1}$, stem caliper of Verbena increased by $0.2 \mathrm{~mm}(11 \%)$ (Fig. 2F), whereas stem caliper of Diascia and Nemesia increased by $1.1(119 \%)$ and $1.2 \mathrm{~mm}$ (89\%), respectively (Fig. 2D-E). Daily light integrals during propagation affected the sturdiness quotient of species differently (Fig.
$2 \mathrm{G}-\mathrm{I})$. Although the sturdiness quotient of Nemesia increased from 0.14 to $0.22(58 \%)$ as DLI during propagation increased from 1.2 to $12.3 \mathrm{~mol} \cdot \mathrm{m}^{-2} \cdot \mathrm{d}^{-1}$ (Fig. $2 \mathrm{H}$ ), the sturdiness quotient of Angelonia, Diascia, Lantana, Scaevola, Sutera, and Verbena was unaffected by DLI during propagation (Fig. $2 \mathrm{G}-\mathrm{I}$ ).

Quality. The quality index increased differently for all species as DLI during propagation increased (Fig. 3A-C). For example, although the quality index of Lantana increased by $63(53 \%)$ (Fig. 3B) as DLI increased from 1.2 to $12.3 \mathrm{~mol} \cdot \mathrm{m}^{-2} \cdot \mathrm{d}^{-1}$, the quality index of Diascia increased by 78 (960\%) (Fig. 3A).

\section{Discussion}

An important characteristic of seedlings and rooted cuttings is overall growth or biomass accumulation during propagation (Lopez 


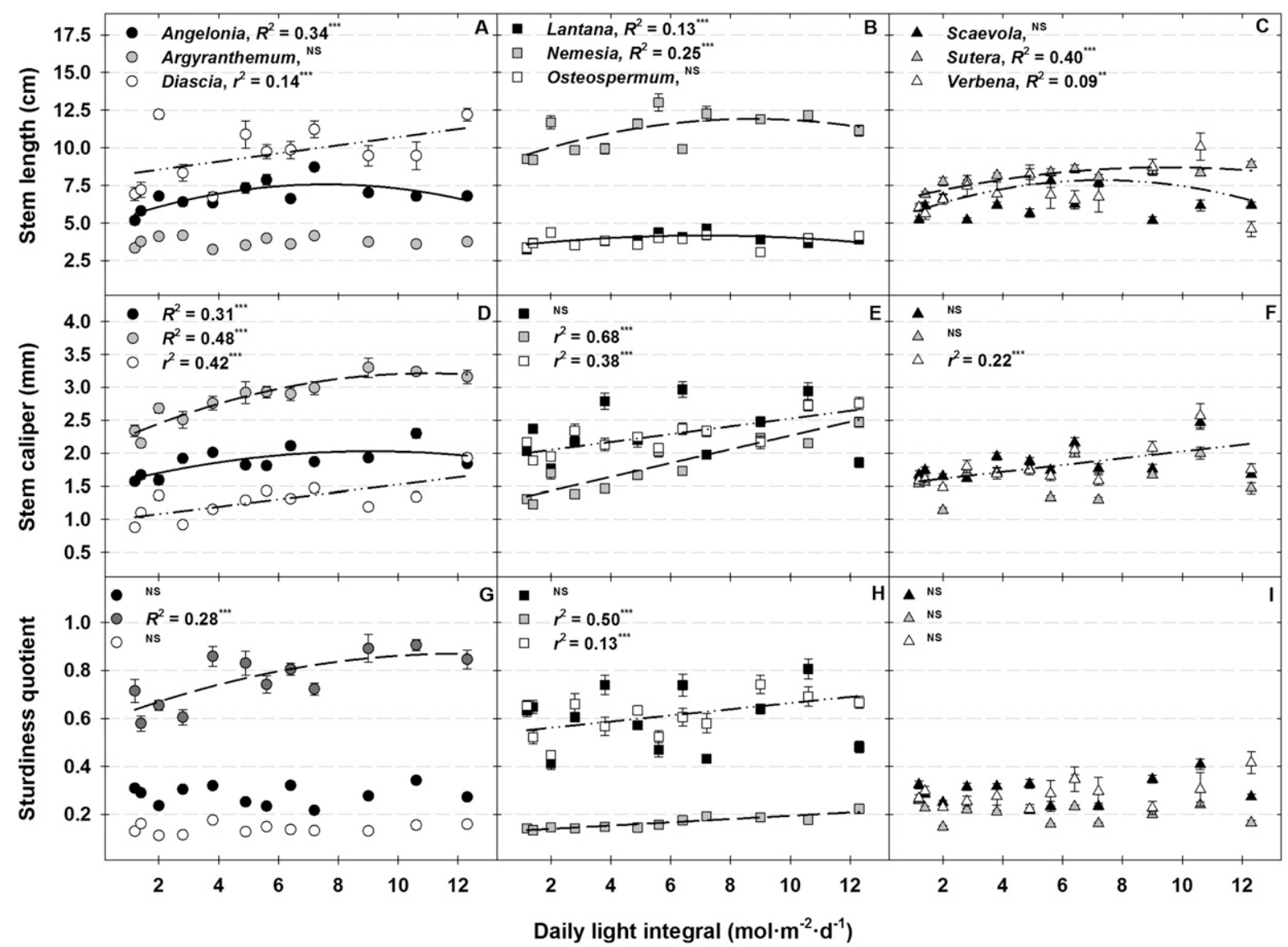

Fig. 2. (A-I) Relationships between mean daily light integral (DLI) and shoot length, stem caliper, and sturdiness quotient of Angelonia, Argyranthemum, Diascia, Lantana, Nemesia, Osteospermum, Scaevola, Sutera, and Verbena measured after $14 \mathrm{~d}$ under different DLIs during propagation. Each symbol represents the mean of 10 plants, and error bars represent SES of the mean. Regression lines are presented for significant correlations only with corresponding $r^{2}$ and $R^{2}$ presented. Ns, ${ }^{*}, * * * * *$ indicates nonsignificant or significant at $P \leq 0.05,0.01$, or 0.001 , respectively. Species are grouped alphabetically within rows from $\mathrm{L}$ to $\mathrm{R}$ for each dependent variable.

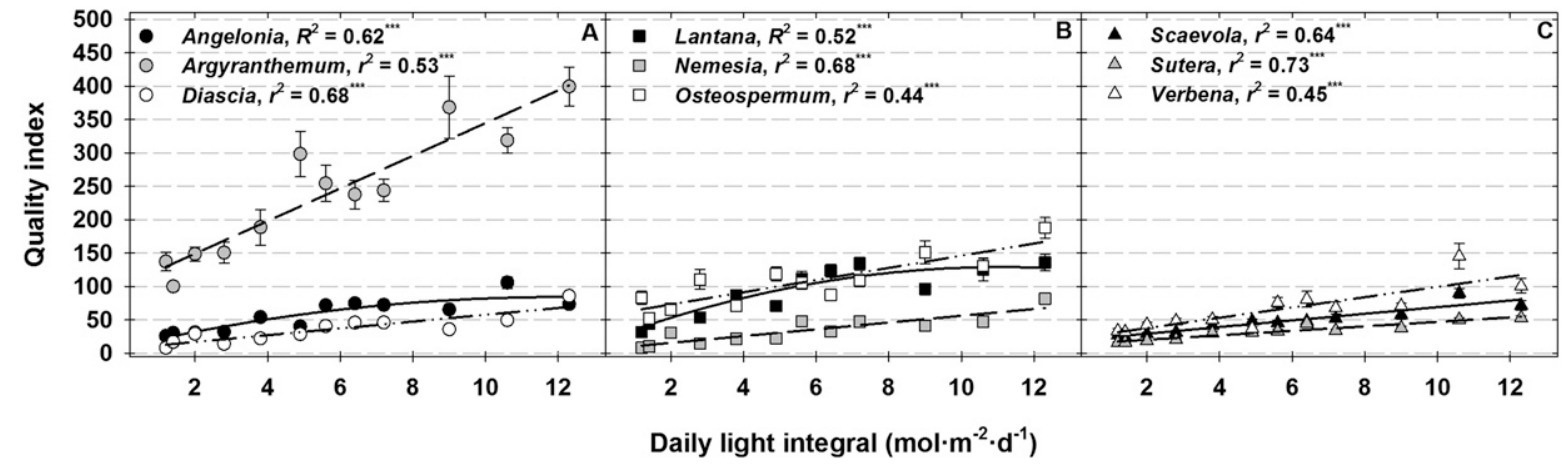

Fig. 3. (A-C) Relationships between mean daily light integral (DLI) and quality index of Angelonia, Argyranthemum, Diascia, Lantana, Nemesia, Osteospermum, Scaevola, Sutera, and Verbena after $14 \mathrm{~d}$ under different DLIs during propagation. Each symbol represents the mean of 10 plants, and error bars represent sEs of the mean. Regression lines are presented for significant correlations only with corresponding $r^{2}$ and $R^{2}$ presented. Ns, *,**,*** indicates nonsignificant or significant at $P \leq 0.05,0.01$, or 0.001 , respectively. Species are grouped alphabetically within rows from $\mathrm{L}$ to $\mathrm{R}$ for each dependent variable.

and Runkle, 2008; Pramuk and Runkle, 2005). Biomass accumulation tends to be positively correlated with light during propagation (Graper and Healy, 1991; Lopez and Runkle, 2008; Oh et al., 2010; Pramuk and Runkle, 2005; Torres and Lopez, 2011), and this relationship was observed for all species tested in our study (Fig. 1A-C). All species exhibited increased shoot dry mass in response to increasing DLI during propagation (Fig. 1D-F), a trend consistent with other studies of young plant production and DLI (Lopez and Runkle, 2008; Pramuk and Runkle, 2005; Torres and Lopez 2011). Similarly, we observed an increase in root dry mass in response to increasing DLI for each species (Fig. 1G-I). Lopez and Runkle (2008) reported that root dry mass of 'Celebrette Red', 'Harmony Magenta', and 'Harmony White' New Guinea impatiens and 'Double Wave Spreading Rose', 'Supertunia Mini Purple', and 'Tiny Tunia Violet Ice' petunias all increased with increasing DLI during propagation (Lopez and Runkle, 2008) Of particular interest to cutting propagators is the impact of DLI on root growth. For a rooted cutting to be considered ready for transplant and saleable, it must have a large enough root mass so that the plug may be easily removed from the propagation tray, termed a "pullable plug" (Lopez and Runkle, 2008). Our results, when taken together with Lopez and Runkle (2008), clearly indicate that increasing DLI during propagation of herbaceous annual 
shoot-tip cuttings increases root growth, can increase rooted cutting quality, and potentially reduce production time. Although all producers of rooted cuttings could realize energy and labor savings as a result of reduced production time, increasing the DLI during propagation with supplemental lighting would be particularly beneficial for growers at northern latitudes (Runkle, 2010), where DLIs in greenhouses are low and heating costs are high during late winter and early spring (Korczynski et al., 2002; Runkle et al., 2009).

Although higher overall biomass for young plants is generally desirable, assessing biomass partitioning into shoot and root growth is an important consideration for seedlings and rooted cuttings, because luxurious shoot growth at the expense of root growth is not desirable in transplant production. We observed that when root and shoot dry mass were taken together, the root:shoot dry mass ratio increased with DLI for all species in this study (Fig. 1J-L). The root:shoot dry mass ratio of three New Guinea impatiens cultivars and three petunia cultivars all increased with increasing DLI during propagation (Lopez and Runkle, 2008). Therefore, it appears that increasing the DLI during propagation of cuttings not only increases shoot and root growth, but partitioning of biomass into roots is favored during propagation of rooted cuttings under increasing DLI.

The effects of DLI during propagation on stem length varied with species in this study (Fig. 2A-C). Our data on the relationship between stem length and DLI during propagation are comparable with the variation reported in other studies on DLI and propagation (Lopez and Runkle, 2008; Pramuk and Runkle, 2005; Torres and Lopez, 2011). For example, Torres and Lopez (2011) reported that as DLI during propagation increased from 0.75 to 25.2 $\mathrm{mol} \cdot \mathrm{m}^{-2} \cdot \mathrm{d}^{-1}$, height of Tecoma stans (L.) Juss. ex Kunth (tecoma) 'Mayan Gold' seedlings increased by $3.5 \mathrm{~cm}$. However, in another study (Pramuk and Runkle, 2005), stem length of Celosia argentea var. plumosa L. 'Gloria Mix' and Tagetes patula L. 'Bonanza Yellow' increased with increasing DLI during propagation, whereas stem length of Impatiens wallerana Hook. 'Accent Red' and Salvia splendens Sell. ex Roem. \& Schult. 'Vista Red' decreased with increasing DLI. When cuttings of 'Tiny Tunia Violet Ice', 'Double Wave Spreading Rose', and 'Supertunia Mini Purple' petunia and 'Celebrette Red', 'Harmony Magenta', and 'Harmony White' New Guinea impatiens were propagated under DLIs ranging from 1.2 to $5.9 \mathrm{~mol} \cdot \mathrm{m}^{-2} \cdot \mathrm{d}^{-1}$, shoot height decreased for all petunia cultivars as DLI increased and stem length of New Guinea impatiens was unaffected by DLI (Lopez and Runkle, 2008). Similarly, we found no differences in stem length of rooted cuttings of 'Magnum Salmon' New Guinea impatiens cuttings propagated under DLIs ranging from 2.5 to $15.6 \mathrm{~mol} \cdot \mathrm{m}^{-2} \cdot \mathrm{d}^{-1}$ (unpublished data). Faust et al. (2005) reported there were no consistent trends in the height across eight annual bedding plant species grown under DLIs ranging from 5 to 45 $\mathrm{mol} \cdot \mathrm{m}^{-2} \cdot \mathrm{d}^{-1}$, indicating similar variation on the effect of DLI during finishing on plant height or stem length. When these data are taken together with the results of our study, it appears that DLI influences stem length of species differently and the cause of this variation remains unknown.

Pramuk and Runkle (2005) stated that transplants with larger stem caliper were desired for commercial production for easier handling and transplanting. We observed an increase in stem caliper for six of the nine species used in this study in response to increasing DLI during propagation (Fig. 2D-F). There are few reports of the effect of DLI during propagation on stem caliper of seedlings and cuttings. Torres and Lopez (2011) reported that as DLI during propagation increased from 0.75 to $25.2 \mathrm{~mol} \cdot \mathrm{m}^{-2} \cdot \mathrm{d}^{-1}$, stem caliper of 'Mayan Gold' tecoma increased by $1.2 \mathrm{~mm}(233 \%)$. Similarly, we found that after $14 \mathrm{~d}$ in propagation, stem caliper of 'Magnum Salmon' New Guinea impatiens increased from 3.9 to $5.4 \mathrm{~mm}$ as DLI increased from 2.5 to $15.6 \mathrm{~mol} \cdot \mathrm{m}^{-2} \cdot \mathrm{d}^{-1}$ (unpublished data). It appears that increasing DLI during propagation either increases or has no effect on stem caliper, depending on the species.

Another desirable characteristic of rooted cuttings is that they appear "sturdy" when shipping rooted cuttings from propagators to finish growers and subsequent forcing after transplant. The sturdiness quotient is the ratio of stem caliper to stem length (Thompson, 1985), and although we have found no reports of using the sturdiness quotient to assess young herbaceous plants, we feel that the sturdiness quotient accurately describes the strength of a rooted cutting. In our study, we found that the sturdiness quotient increased for Argyranthemum, Nemesia, and Osteospermum (Fig. 2GH). Although stem caliper of Angelonia, Diascia, and Verbena increased with DLI, stem length of these species increased proportionally to stem caliper with increasing DLI. A common practice in cutting propagation is to shear or trim a tray of fully rooted cuttings to remove excess shoot growth. If growers were to propagate cuttings under higher DLIs and trim excess shoot growth, rooted cuttings could have a high sturdiness quotient as a result of a large stem caliper as a result of high DLI and shortened stem length from trimming.

When total dry mass, sturdiness quotient, and root:shoot dry mass ratio are taken together, the quality index of all species in our study increased with DLI during propagation (Fig. 3A-C). The quality index was originally designed for assessing the quality of Picea abies (L.) H. Karst. and Pinus strobus L. seedlings produced for forestry purposes based on growth and morphological characteristics and indices that were positively correlated with post-transplant growth (Dickson et al., 1960). To our knowledge, this is the first herbaceous greenhouse crop study to use the quality index as an objective, integrated, and quantitative measurement of quality. Although growth and morphology may not directly reflect the physiological status of a rooted cutting or seedling per se, it does indicate the potential for subsequent growth and development of a young plant after transplanting (Thompson, 1985) and has been validated for use as an indicator of posttransplant success (Ritchie, 1984). As a result, the use of the quality index as a quantitative measurement of seedling or rooted cutting quality could assist researchers and producers in assessing the effect of various environmental conditions and cultural practices on young plant quality.

\section{Conclusions}

The results of our research indicate that increasing the DLI during propagation with supplemental lighting can increase shoot and root growth, impact morphology, and, therefore, increase overall quality of rooted cuttings of the nine herbaceous annual plants used in this study. However, in addition to increasing overall quality, increasing root growth may lead to reduced production time of rooted cuttings. Based on our results, we recommend that cutting propagators provide $\approx 10$ $\mathrm{mol} \cdot \mathrm{m}^{-2} \cdot \mathrm{d}^{-1}$ during root development to increase growth and quality of most annuals used in this study. When DLIs inside a greenhouse are below $10 \mathrm{~mol} \cdot \mathrm{m}^{-2} \cdot \mathrm{d}^{-1}$, we suggest providing supplemental light to achieve 10 $\mathrm{mol} \cdot \mathrm{m}^{-2} \cdot \mathrm{d}^{-1}$, although the amount of supplemental lighting necessary will vary with greenhouse structure, location, and time of year.

Our results expand the general understanding of how increasing the DLI during propagation impacts growth and morphology of rooted cuttings using supplemental photosynthetic lighting. However, the lack of understanding of how DLI affects the physiology of cuttings in propagation warrants further investigation into how DLI impacts carbohydrate, chlorophyll, and gas-exchange dynamics of cuttings undergoing ontogenic changes.

\section{Literature Cited}

Dickson, A., A. Leaf, and J.F. Hosner. 1960. Quality appraisal of white spruce and white pine seedling stock in nurseries. For. Chron. $36: 10-13$

Dole, J.M., J.L. Gibson, and H.F. Wilkins. 2006. Crop-by-crop cutting propagation, p. 229-361. In: Dole, J.M. and J.L. Gibson (eds.). Cutting propagation: A guide to propagating and producing floriculture crops. Ball Publishing, Batavia, IL.

Erwin, J.E. 1994. Aesexual propagation, p. 363378. In: Holcomb, E.J. (ed.). Bedding Plants IV. Ball Publishing, Batavia, IL.

Faust, J. 2004. Research highlight: The effect of hanging baskets on the greenhouse light environment, p. 36. In: Fisher, P. and E. Runkle (eds.). Lighting up profits: Understanding greenhouse lighting. Meister Media Worldwide, Willoughby, OH.

Faust, J.E., V. Holcombe, N.C. Rajapakse, and D.R. Layne. 2005. The effect of daily light integral on bedding plant growth and flowering. HortScience 40:645-649.

Graper, D.F. and W. Healy. 1991. High pressure sodium irradiation and infrared radiation accelerate Petunia seedling growth. J. Amer. Soc. Hort. Sci. 116:435-438. 
Hanan, J.J. 1998. Radiation, p. 91-166. Greenhouses: Advanced technology for protected horticulture. CRC Press, Inc., Boca Raton, FL.

Korczynski, P.M., J. Logan, and J.E. Faust. 2002. Mapping monthly distribution of daily light integrals across the contiguous United States. HortTechnology 12:12-16.

Lambers, H., F.S. Chapin, III, and T.J. Pons. 2008. Photosynthesis, respiration, and long-distance transport, p. 11-99. Plant physiological ecology. 4th Ed. Springer, New York, NY.

Larcher, W. 2003. The environment and plants, p. 167. In: Physiological plant ecology: Ecophysiology and stress physiology of functional groups. 4th Ed. Springer-Verlag, Berlin, Germany.

Lopez, R.G. and E.S. Runkle. 2008. Photosynthetic daily light integral during propagation influences rooting and growth of cuttings and sub- sequent development of New Guinea impatiens and petunia. HortScience 43:2052-2059.

Oh, W., E.S. Runkle, and R.M. Warner. 2010. Timing and duration of supplemental lighting during the seedling stage influence quality and flowering in petunia and pansy. HortScience 45:1332-1337.

Pramuk, L.A. and E.S. Runkle. 2005. Photosynthetic daily light integral during the seedling stage influences subsequent growth and flowering of Celosia, Impatiens, Salvia, Tagetes, and Viola. HortScience 40:1336-1339.

Ritchie, G.A. 1984. Assessing seedling quality, p. 243-259. In: Duryea, M.L. and T.D. Landis (eds.). Forest nursery manual: Production of bareroot seedlings. Martinus Nijhoff Publishers, Hague, The Netherlands.

Runkle, E. 2010. Supplemental lighting guidelines for young plants. Greenhouse Product News 10:50.
Runkle, E., J. Frantz, and M. Blanchard. 2009. Energy efficient annuals: Scheduling bedding plants. Greenhouse Grower 27:40, 42, 44.

Thompson, B.E. 1985. Seedling morphological evaluation- What you can tell by looking, p. 59-71. In: Duryea, M.L. (ed.). Evaluating seedling quality: Principles, procedures, and predictive abilities of major tests. Forest Research Laboratory, Oregon State University, Corvallis, OR.

Torres, A.P. and R.G. Lopez. 2011. Photosynthetic daily light integral during propagation of Tecoma stans influences seedling rooting and growth. HortScience 46:282-286.

U.S. Department of Agriculture. 2011. Floriculture crops 2010 summary. Nat. Agr. Sta. Service, Washington, DC. 26 May 2011. <http://usda. mannlib.cornell.edu/usda/current/FlorCrop/ FlorCrop-04-21-2011_new_format.pdf $>$. 